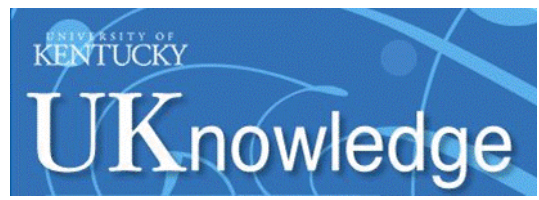

University of Kentucky

UKnowledge

Superfund Research Center Faculty

Publications

Superfund Research Center

3-1-2017

\title{
Environmental Challenges in Central and Eastern Europe
}

Bernhard Hennig

University of Kentucky, bhennig@uky.edu

Follow this and additional works at: https://uknowledge.uky.edu/superfund_facpub

Part of the Environmental Health and Protection Commons, and the International and Area Studies

Commons

Right click to open a feedback form in a new tab to let us know how this document benefits you.

\section{Repository Citation}

Hennig, Bernhard, "Environmental Challenges in Central and Eastern Europe" (2017). Superfund Research Center Faculty Publications. 3.

https://uknowledge.uky.edu/superfund_facpub/3

This Editorial is brought to you for free and open access by the Superfund Research Center at UKnowledge. It has been accepted for inclusion in Superfund Research Center Faculty Publications by an authorized administrator of UKnowledge. For more information, please contact UKnowledge@lsv.uky.edu. 


\section{Environmental Challenges in Central and Eastern Europe}

Digital Object Identifier (DOI)

https://doi.org/10.1515/reveh-2017-0004

\section{Notes/Citation Information}

Published in Reviews on Environmental Health, v. 32, issue 1-2, p. 1.

@2017 Walter de Gruyter GmbH, Berlin/Boston.

The copyright holder has granted the permission for posting the article here. 


\section{Editorial}

\section{Bernhard Hennig* \\ Environmental challenges in Central and Eastern Europe}

\section{DOI 10.1515/reveh-2017-0004}

This special issue of Reviews on Environmental Health consolidates research articles and reviews that not only focus primarily on environmental challenges in Central and Eastern Europe but also draw connections to environmental health challenges that are common across many international regions. The articles in this special issue exemplify scientific interactions between researchers from the United States and Central and Eastern Europe who have collaborated to tackle mutual environmental health issues using shared expertise. The historical perspectives of this international effort to collectively explore and combine knowledge related to novel remediation technologies and emerging environmental health exposure science is highlighted in the first article by William A. Suk, where practical approaches for reducing exposures and disease outcomes in Central and Eastern Europe are discussed. Subsequent articles and reviews are authored by scientists, engineers, and members from regulatory organizations to provide in depth research data about the challenges of persistent environmental pollution in Central and Eastern Europe, as well as data discussing promising areas for prevention and intervention in these regions. Beyond articles that are specific to the Central and Eastern European region, authors have also prepared articles that discuss emerging topics that are relevant for the entire international community. Areas of emphasis of articles in this special issue include (a) multiple environmental stressors and health status as a variant of disease, with a focus on persistent organic pollutants, metals, mixtures, and new and emerging pollutants, as well as engineered and combustion generated nanoparticles; (b) sustainable exposure prevention through innovative detection and remediation technologies; (c) understanding of population health effects of exposure science, including preventing environmental disease through multilevel interventions; and (d) articles on policies associated with public and global health perspectives, considering environmental pollution a complex and global issue. In summary, the peer-reviewed articles in this special issue span across population health effects, including insights into the exposome and epigenetic effects; environmental disease prevention strategies, including lifestyle factors; and novel environmental remediation technologies and risk assessment, policy implications, and next-generation scientific leadership.

The special issue was critically peer-reviewed, and a special committee of Associate Guest Editors was appointed to delegate and assist with the review process. I wish to give special thanks to (in alphabetical order) Drs. Lisbeth Knudsen, Slawo Lomnicki, Tomas Macek, Kelly Pennell, Michael Petriello, Larry Robertson, and Jan Topinka for all their help to make the peer review process of this special issue a success.

Respectfully submitted, Bernhard Hennig

Guest Editor

*Corresponding author: Bernhard Hennig, Superfund Research, Center, University of Kentucky, 900 S. Limestone Street, Lexington, KY 40536, USA, Phone: + 1 859-218-1343, Fax: + 1 859-257-1811, E-mail: bhennig@uky.edu; and Department of Animal and Food Sciences, College of Agriculture, Food and Environment, University of Kentucky, Lexington, KY 40536, USA 